\title{
Sustainable Agrotourism Curating by Conferring Community Involvement in Tanah Rata, Cameron Highlands, Malaysia.
}

\author{
Ati Rosemary Mohd Ariffin* and Athirah Mohd Irwan Yen \\ Centre for Building, Construction and Tropical Architecture (BuCTA), Faculty of Built \\ Environment, University of Malaya, 50603, Kuala Lumpur, Malaysia. \\ *aa_alambina@um.edu.my
}

\begin{abstract}
The highest number of tourists' arrivals recorded in Cameron Highlands was 728, 121 people. In 2014 , the number declined by $30 \%$ due to landslide events. The main question for this paper is what can be implemented into the tourism strategic planning that may benefit local communities and promote sustainable tourism development in Tanah Rata, Cameron Highlands. The lack of sustainable practice has caused the highlands to degrade and the incentives for agriculture increases in parallel with unequal benefits for locals. There are two key socio economic sustainable tourism concepts which are; community involvement in decision-making and community involvement in tourism benefits sharing being proposed in this paper. Four sets of interview questionnaires were formulated based on 4 components of respondents. Based on the results, this research highlighted that the decision-making process are to be made jointly with the government and local authority in consultation with the community representative. Amongst the recommendations is fair-trade scheme of equity in payment is for locals to benefit off tourism businesses involved in agriculture to protect their working and living environment and gain control over their future. The success of the two concepts requires commitment from all parties.
\end{abstract}

Keywords: community involvement, sustainable tourism, tourism benefits, fair-trade, Cameron Highlands

\section{INTRODUCTION}

Tourism is known to be one of largest industries to date, indirectly and unknowingly tourism is a contributing factor towards issues of global climate changes, loss of biodiversity, cultural diversity, deforestation and migration of locals. Gilpin (2009) emphasised on the four important points in developing tourism. Firstly, virtual peace amongst locals and travelling tourists and degrees of economic development. Second, although tourism possesses the capacity of economic benefits, it may lead to harm if it is not being carefully planned. Third, this is where benefits of tourism are carefully curated with respect to society, cultural traditions and environment. Fourth, tourism development has to be in conjunction with the national visions and strategy and is supported by related authorities and board committees. In regard to the points highlighted, tourism provides contribution in the forms of macro and micro economic development (Bhuiyan, Siwar \& Ismail, 2013).
The tourism industry in Malaysia is experiencing a rapid economic growth over the past five decades (Borji, 2015) as seen in Figure 1. The country received 7.5 million tourist arrivals in 1995 , the number rose up to 10.2 million in 2000 and has jumped to 26.8 million in 2016. The attractions of natural sightseeing and activities are seen as the major pull that brings a significant growth to the tourism development in Malaysia and is growing steadily for more than a decade benefitting the locals directly and indirectly (Isa, 2015). In the case of Tanah Rata, Cameron Highlands, known for its forest reserves and plantations, the consideration of conservation is vital in preserving Cameron Highlands as one of the highlands tourist destinations with minimal impacts. This can be seen through the macro and micro development as described in the following sub topics. 


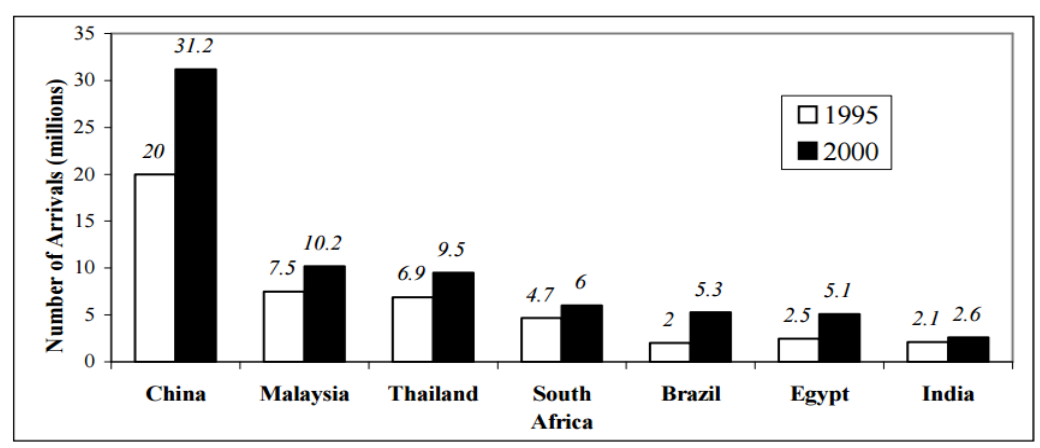

Figure 1: Number of tourists' arrivals of some less developed countries 1995-2000 (WTO Tourism Market Trends in Tearfund 2002, 19).

Source: Journal of the Economic Impacts of Fair Trade in Tourism by Krause (2012).

\section{LITERATURE REVIEW}

Since the mid-1990s, the concept of sustainable tourism appeals as a prior objective in the global tourism sector (Weaver, 2014). Back in 1997, the National Ecotourism Plan was created in accordance with Malaysia's initiative based on the ecotourism definition announced by the World Conservation Union (IUCN) (Hitchner, 2009).

\subsection{Macro Development of Sustainable Tourism}

At macro level of economic development, tourism acts as the catalyst in terms of generating revenues, equity in payment, commodity cost and contribution in the gross domestic production (GDP) (Bhuiyan, Siwar \& Ismail, 2013). Figure 2 shows a table of tourism development's impacts based on economic aspects.

\begin{tabular}{llcc} 
& \multicolumn{1}{c}{ Statements } & \multicolumn{2}{c}{ Percentage (\%) } \\
& Agree & Not Agree \\
\hline (a) Provides more jobs for indigenous people & 78.8 & 21.2 \\
(b) Increases the incomes of indigenous people & 82.3 & 17.7 \\
(c) Increases the economics of indigenous people & 68.9 & 31.1 \\
(d) Increases the prices of house/land & 56.6 & 43.4 \\
(e) Increases daily expenses & 68.9 & 31.1 \\
(f) Attract soutsiders do business within nearby & 52.2 & 47.8 \\
& & \\
(g) More money is required to finance the rising & 71.1 & 28.9 \\
(h) Increases the prices of basic needs & & \\
(i) Increases salaries & 61.1 & 38.9 \\
\end{tabular}

Figure 2: Tourism Development's impact on Economic Aspects.

Source: The Indigenous Community's Perception of Tourism Development in the Cameron Highlands, Malaysia (2010).

The first point highlighted on revenue which is the financial income as well as receipts and earnings of a certain organisation (Investopedia, 2003). It describes how revenue generation is done by promoting tourism practices. Moreover, equity in payment is related to fair trade which is linked to commodities. When the fair-trade mark first emerged, it has been known widely in various sectors and known to be appreciated (Krause, 2012). As stated by Krause (2012), Tearfund (2002) conducted researches that shown local goods produced in a producer-friendly process attract consumers that are willing to pay higher. This means that the locals or host country will gain more benefits. Fair trade in tourism has no standards or labelling of fair trade products, thus, they are still in the midst of developing phase (Krause, 2012). Fair trade refers to goods or products at better prices in a decent working environment accompanied by fair trade terms for all farmers and workers (Fairtrade Foundation, 2016). Fairtrade Foundation (2016) based in UK emphasised the concept of supporting the communities' development involved in farming protect their working and living environment and gain control over their future to improve their living conditions in the thriving industry. Fair trade derives from two developments as mentioned by Bowen $(2001,35)$ which are professionalisation in the movement and strong dimensions (Krause, 2012). For instance, 
Finland has shown success in their fair-trade products of $30 \%$ sales increment, one of it being coffee production. In relations to equity, this portrays how important professionalisation and commitment is when it comes to fair trade. With the fair-trade awareness to date, Malaysia agriculture or agro tourism should implement these schemes. Hence, an ongoing effort of professionalisation in the movement needs to be emphasised to avoid economic imbalance and environmental loss in Cameron Highlands.

As argued by Abidin (1999), the National Ecotourism Plan guidelines for Malaysia do not portray the specific mechanisms in monitoring and evaluating the future management for sustainable tourism. "There are also no criteria and indicators developed for sustainable tourism management and biological diversity conservation in the protected areas of Malaysia", said Abidin (1999). Due to the lack of criteria and indicator for sustainable tourism development, Malaysia has its fair share of challenges to ensure development is compatible with conservation of the protected areas. Based on what Hitchner (2009) highlighted in one of her Journals of Ecotourism, study by Lim (1999) (discussed in Mohamed, 2002) discovered the issues faced by travel agencies while advertising ecotourism:

- $\quad$ The agency is of 4 to 6 years old working experience

- The eco-travelling tourist guides have no proper training and education; does not own proper license for areas that are protected.

- Only $11.9 \%$ of travel agencies inform the tourists regarding the purchase of banned items.

- Less than $46 \%$ of travel agencies are unware of the local community

- $30.8 \%$ have no relations towards the government

- 10 out of 15 travel agencies do not understand the concepts of ecotourism

- $80 \%$ of the activities are not associated with the social, cultural or environmental aspect

\subsection{Micro Development of Sustainable Tourism}

At the micro level of economic development, the impetus of tourism stems from community involvement, income distribution, employment opportunities, carrying capacity and sustainable regional developments (Bhuiyan, Siwar \& Ismail, 2013). The micro level focuses more on the impact it brings to the society, culture and environment.

Society aspects of tourism revolve around the local community. In order for tourism to provide stability through community involvement, there are three main constituencies' actions that can be engaged. As mentioned by Honey \& Gilpin (2009), they are host communities, host governments and foreign stakeholders.

On sustainable tourism curating through community involvement, this study shall focus on ways to engage the host communities. Host community is a fundamental component in tourism development (Lorton Consulting, 2011). The component consists of three key subject matters which are the tourist, the resource and the host. Cameron Highlands is known for its nature tourism, and activities related to the natural possession there bring impacts towards the host community. In this paper, the host community in Cameron Highlands refers to the local community, Orang Asli and foreign workers. In order to partake effectively for stability, tourism activities should respect local culture and environment. As for the host governments, described by Honey \& Gilpin (2009), their role is to establish national tourism strategies with robust laws to provide protection over tourist sites and for the people who work in the tourism industry. Apart from that, host governments should address constraints and bottlenecks in tourism industry to ensure that this sector is not being undermined at local or national levels by overlapping departments. Lastly, host governments should acquire creative marketing strategy of the tourism industry as it the industry is getting competitive.

Community involvement can be built through skills, mastery and extensive knowledge in a plantation, forestry and farming by the host community. The population of Cameron Highlands based on the year 2000 Census is 30, 495 and in the year 2010 Census increased to 38, 471 data from Department of Statistics Malaysia (2010). The population includes the legal foreign workers and can be seen in Figure 3 (a). The migration of locals' issue stems from the employment of foreign workers. Cameron Highlands have a strong indigenous people population. The Orang Asli are of different ethnicity; they are Semai (96.7\%), Semalai (1.1\%) and Temiar (2.2\%). Total of $44.4 \%$ of the Orang Asli are selfemployed and others work in different sectors 
(Salleh, 2010). The remaining are mostly Malays and Chinese. The locals no longer find the income distribution of working in the agriculture sectors reasonable. The distribution range of income is between RM501-RM1500 for the $42 \%$ of the working class, and $38 \%$ of them receives less than RM500 monthly (Salleh, 2010). This results to the locals finding better job opportunities at nearby cities causing an influx of foreign legal and illegal workers to Cameron Highland.

TOTAL POPULATION BY ETHNIC GROUP (2010)
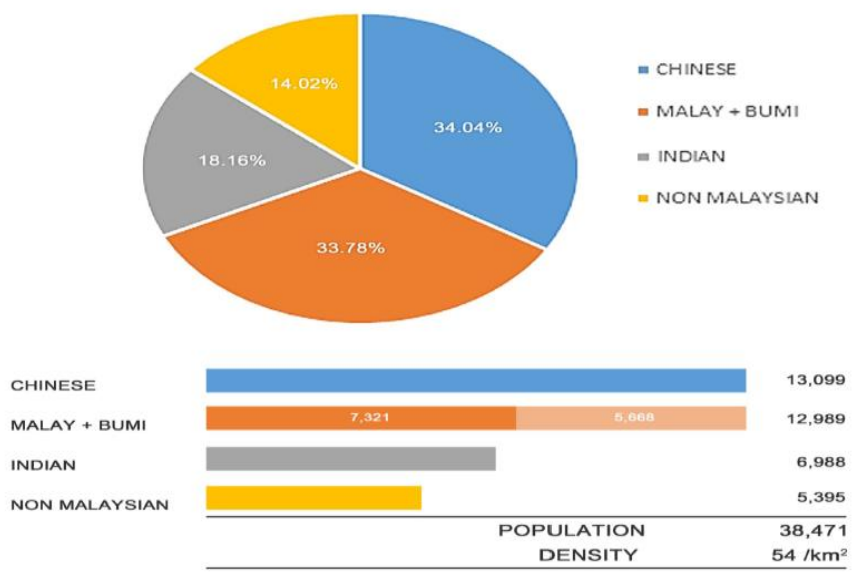

Figure 3. (a): Total population by ethnic group (2010).

Source: Population Distribution and Basic Demographic characteristics 2010, Department of Statistics, Malaysia (2016).

\section{RESEARCH METHODOLOGY}

This study will highlight the environmental constraints and limitations and suggest solutions on how curation tourism development with strong community involvement through a suitable tourism programme may remedy and enhance the environment.

Through appropriate content curation, the tourism programme with community involvement is to demonstrate how it can be one of the sustainable economic drive forces with respect to the social and environmental aspects. The aim is to raise awareness on the environmental impacts of a highland area and educates the locals on nature-based tourism or agro based tourism and offer better pay to the locals of Cameron Highlands.

The sequence of the methodological stage is site observation, identify target group, formulation of questionnaire and pilot test. Purposeful samplings was employed by selecting those involved or have acquired knowledge in the field relating to tourism, tourism management, highlands, environmental impact assessment and community development. They are the head departments of the local authority, planners, community representatives/village headman, nongovernmental organisations (NGO), engineers, environmental managers and professionals of tourism management and business expertise.

\subsection{Site Observation}

Site observation is carried out through self-site observation supported with desk-top research, image-based research and secondary data from related organisations and other researchers. The site visit to Cameron Highlands is to study the existing condition of Tanah Rata and Cameron Highlands and observe the local environment and setting as a growing tourist attraction and destination area.

The observation is to examine the impacts of tourism in terms of social, environmental and economic aspects. Through site observation, the questionnaires are formulated and prepared to also meet the expected outcomes out of each of the research objective.

**Next following page contains the research methodological framework. 

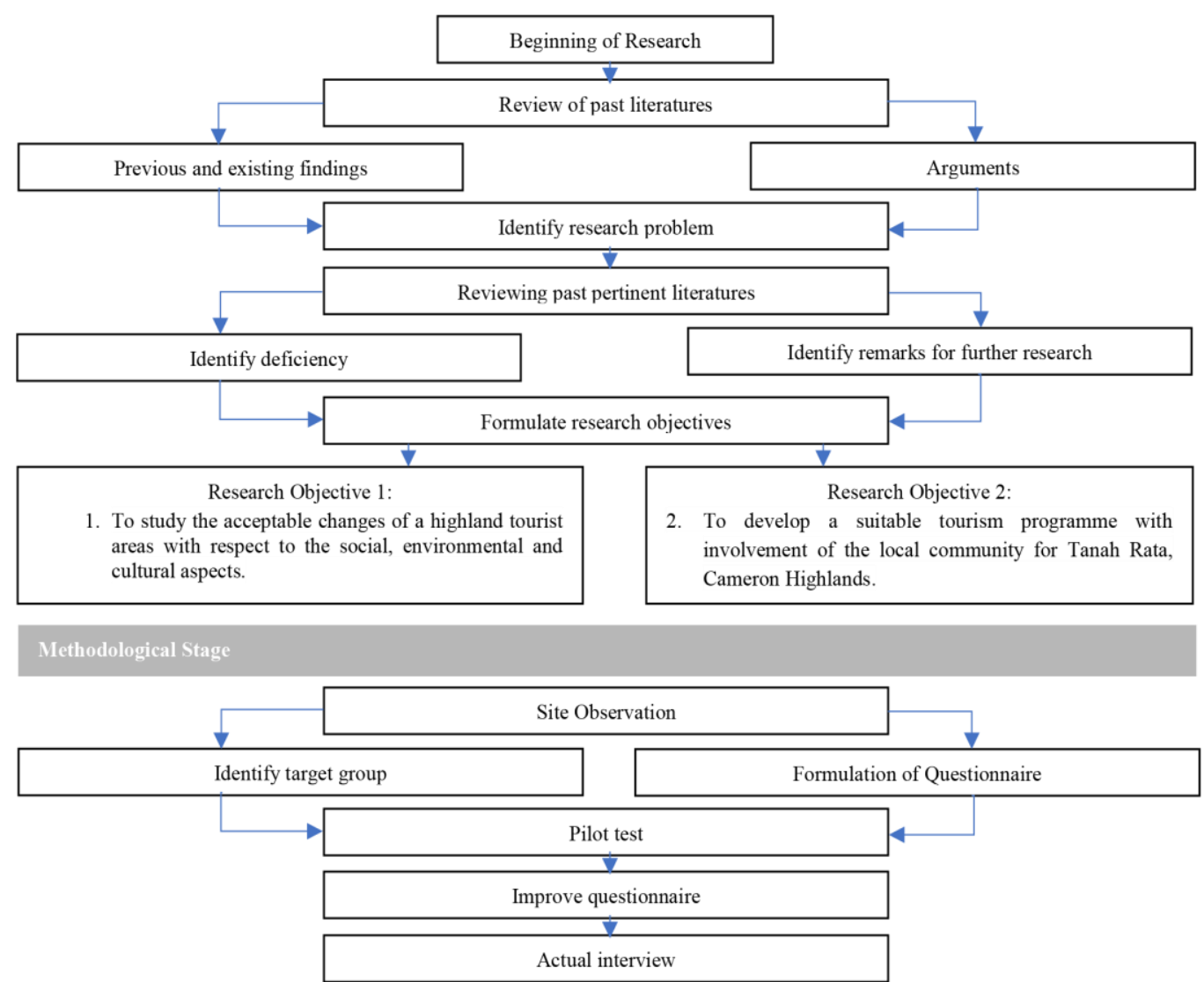

Analysis Stage

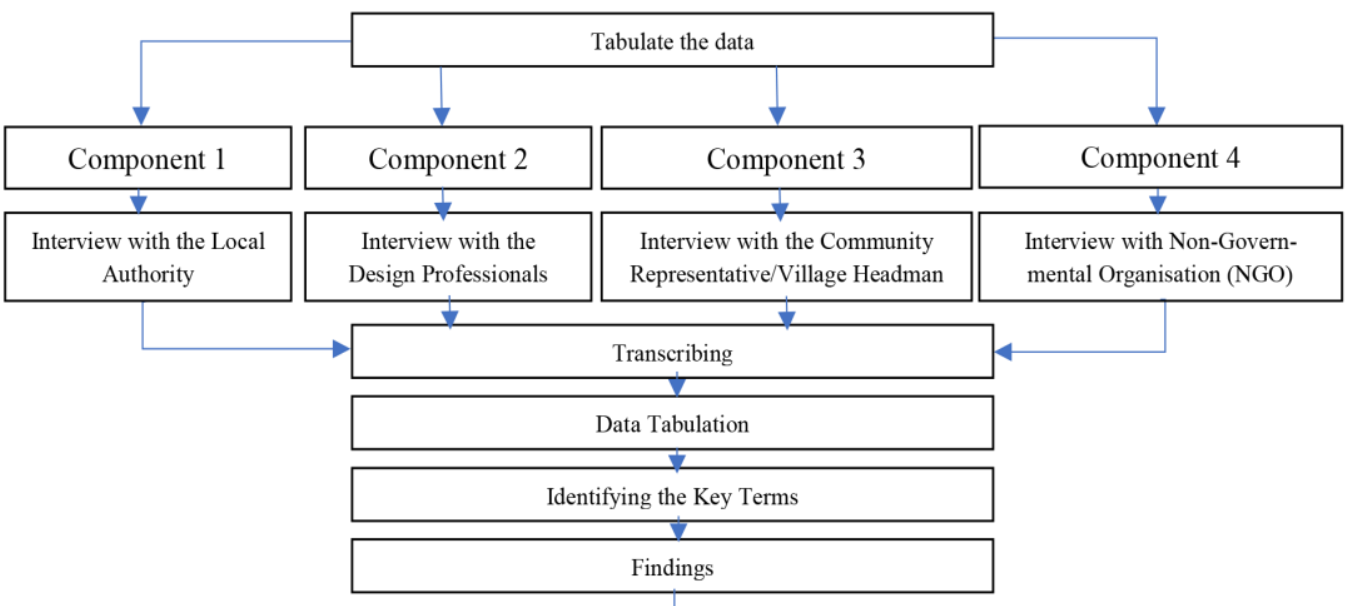

Outcome Stage 


\subsection{Identify Target Group}

The study is broken down into several fields to select participants based on their knowledge and characteristics. This sampling method is to select professionals from different field to provide specific knowledge that are related and deemed to be relevant to the study. Table 1 briefly describes the expertise and expected outcome of each field. Subsequently to site observation and pilot test, the questionnaires are improved based on the site condition and target group for the actual interview to be carried out

Table 1: Expertise \& Expected outcome of the target group and field

\begin{tabular}{|c|c|c|}
\hline Field & Expertise & Expected Outcome \\
\hline Engineering & $\begin{array}{l}\text { Geo-technical engineering, } \\
\text { Ecological engineering, Eco- } \\
\text { engineering and protection \& } \\
\text { Environmental Impact } \\
\text { assessment. }\end{array}$ & $\begin{array}{l}\text { This field is to gain an understanding on the } \\
\text { physical conditions and acceptable changes of } \\
\text { an eco-sensitive highland area as well slope } \\
\text { suitability. }\end{array}$ \\
\hline Environmental & $\begin{array}{l}\text { Highland zonation, } \\
\text { Environmental Impact } \\
\text { Assessment, Environmental } \\
\text { Awareness, Eco-tourism, } \\
\text { Environmental Law \& } \\
\text { Management. }\end{array}$ & $\begin{array}{l}\text { This field is to gain an understanding on the } \\
\text { environmental impact assessment of eco- } \\
\text { sensitive highland areas. Apart from that it is to } \\
\text { understand the environmental awareness and } \\
\text { steps of environmental management and } \\
\text { relations towards eco-tourism. }\end{array}$ \\
\hline $\begin{array}{l}\text { Local } \\
\text { Authority }\end{array}$ & $\begin{array}{l}\text { Department of Health \& } \\
\text { Municipal Services, Landscape } \\
\text { \& Environmental Cases. }\end{array}$ & $\begin{array}{l}\text { This field is to gain an understanding on the } \\
\text { local planning, municipal services, landscape } \\
\text { and environmental cases in conjunction with } \\
\text { the national visions and strategies. }\end{array}$ \\
\hline Planning & $\begin{array}{l}\text { Town \& Country Planning, } \\
\text { Tourism planning and impacts } \\
\text { management. }\end{array}$ & $\begin{array}{l}\text { This field is to gain an understanding on local } \\
\text { planning in conjunction with Department of } \\
\text { Environment (DOE) and Ministry of Tourism } \\
\text { and Culture Malaysia (MOTAC) }\end{array}$ \\
\hline $\begin{array}{l}\text { Community } \\
\text { Representative }\end{array}$ & $\begin{array}{l}\text { Village headman, Community } \\
\text { interest. }\end{array}$ & $\begin{array}{l}\text { This field is to gain an understanding on the } \\
\text { interests of the community with respect to } \\
\text { social, environmental and economic aspects. }\end{array}$ \\
\hline $\begin{array}{l}\text { Tourism } \\
\text { Management }\end{array}$ & $\begin{array}{l}\text { Tourism management and } \\
\text { business, tourism management } \\
\text { economics \& marketing. }\end{array}$ & $\begin{array}{l}\text { This field is to understand tourism management } \\
\text { and marketing. It is to show how community- } \\
\text { based tourism can be one of the economic drive } \\
\text { forces. }\end{array}$ \\
\hline $\begin{array}{l}\text { Non- } \\
\text { governmental } \\
\text { Organisation } \\
\text { (NGO) }\end{array}$ & $\begin{array}{l}\text { Technical assistance \& training, } \\
\text { facilitate communication for } \\
\text { local community }\end{array}$ & $\begin{array}{l}\text { This field is to gain an understanding on a } \\
\text { community-based organization and their } \\
\text { initiatives on the social, economic and } \\
\text { environmental aspects. It is also to identify } \\
\text { their views on community-based tourism and } \\
\text { eco-tourism management. }\end{array}$ \\
\hline
\end{tabular}

\subsection{Respondents}

The respondents comprised of three (2) engineers, one (1) environmental managers, one (1) community representative to represent Tanah Rata, one (1) to two (2) from nongovernmental organisation representing Cameron Highlands, two (2) government officers from the local authority, one (1) to two (2) planners and one (1) professional from the tourism management field.
The interviews for all four components are open-ended questionnaires and designed based on the references of related expertise to meet their characteristics, knowledge and practical interests. Different sets of questionnaires are prepared based on their expertise, however, questions regarding community involvement, development and community interests were repeated in all four components to get a firm understanding of the views on tourism as well as the community in Tanah Rata and Cameron Highlands in general. Questions regarding 
environmental issues and awareness are also repeated and sampled in all four components to record and analyse their opinions of the ongoing trends.

Insufficient time in data collection and securing interviews were the main constraints; hence restrictions was to only 1-3 interviews per field study to establish substantial data.

\subsection{Approach}

A qualitative approach is selected in order to further understand the responses from each participant based on the formulation of questionnaire. The questionnaires are based on the references of key documents which are Standards of Ecotourism by Weaver \& Lawton (2007), Cameron Highlands District Council Local Plan 2003-2015 (2015) and the Guidelines for Development of Resort and Hotel Facilities in Hill Station by Department of Environment December 2009 (DOE) (2009).

The Standards of Ecotourism by Weaver \& Lawton (2007) also stated the five important criteria that are needed to be implemented to ensure sustainability in tourism. Standards of Ecotourism (Weaver \& Lawton, 2007):

1) Protection of the Ecosystem

i) Maintenance of the ecosystem where the ecotourism attraction is located

ii) Protection and maintenance of wildlife especially endangered species

iii) Wildlife live harmoniously with people

2) Maintenance of the physico-chemical conditions of the area

i) Maintenance of the quality of fresh water and marine resources

ii) No wastes overflow and contamination of environment (water, soil \& air)

3) Conservation of local culture and history

i) Culture of locality is maintained

ii) Historical structures are maintained as part of cultural heritage

4) Infrastructures and signboards blend with the environment

5) Sustainability

i) Maintenance of Carrying Capacity of the environment; ii) Environmental education program is part of the ecotourism package;

iii) Livelihood must benefit more the local community than outside entrepreneurs;

iv) The local government supports the ecotourism project through ordinances and resolutions; and

v) The Management Board (community-based) and appropriate government agencies, support the project through strict enforcement of environmental laws;

vi) Experience and product management should follow principles and practices associated with ecological, socio-cultural and economic sustainability.

\section{RESULTS \& FINDINGS}

The findings are based on the outcome of the interview process and sessions held with selected participants divided into four components. The key themes of each component are described as the followings: -

- Component 1: Interview with the Local Authority

$>$ Long-term Plan for Community Engagement and Involvement

$>$ Resources and Budgets for Suitable Tourism Programme

- Component 2: Interview with the Design Professionals

$>$ Issues and Impacts of Cameron Highlands' Environmental Degradation

$>$ Limitations of Tourism Development in Cameron Highlands

$>$ Goals of Community-based Tourism Programm Component 3: Interview with Community Representative

$>$ Issues and Impacts of Tourism to the Community

$>$ Suitable Tourism Programme with Community Involvement

- Component 4: Interview with the NonGovernmental Organisation (NGO)

$>$ Suitable Tourism Programme with Community Involvement

$>$ Resources and Budgets for Suitable Tourism Programme

Implementation of Community-based Tourism in terms of Social, Economic and Environmental Aspects

Component 1: Interview with The Local Authority 
Long-Term Plan for Community Engagement and Involvement

R1 described the community involvement programme from a landscape perspective while R2 described the community, involvement based on the health and municipality perspective. Both respondents are focused more on long-term plan with programmes being held annually

A target is set based on guidelines from ILAM with no policy involved. If there are any policy, it is under Cameron Highlands District Council. It is long term not only involving Cameron Highlands District Council, but also Cameron Highlands District and Land Office, Department of Environment Cameron Highland and Department of Agriculture. Every year, a meeting is held with all of these departments to form a team and design a programme. The tree planting programme involving the community is held annually.

(Respondent 1)

The Resident Representative Office holds the role as our housing ministry with 20 resident representative members in Cameron Highlands. At the moment, Tanah Rata, Brinchang and Kampung Raja is led by one (1) resident representative member. Community involvement programme that has been implemented by the Resident Representative Office is in the Taman Sedia Village led by one resident representative member. Before resident representative, the special committee focused on the marketing for tourism purposes. Secondly, in Pahang overall, the Solid Waste Management and Public Cleansing Act of Act 673 under SW Corp implemented the ' $3 R$ ' Programme which is a long-term plan held with the community.

(Respondent 2)

\section{Resources and Budgets for Suitable Tourism Programme}

R1 described development fund as one of the resources to develop tourism programme while $\mathrm{R} 2$ described the funds from income tax as one of the resources. Based on the Local Agenda of LA 21, there is an amount provided by the Ministry of Local Government and Housing.
In terms of capital, we have our vote of development fund. For instance, an amount of RM100,000 of development fund involving community and other departments is to ensure the programme runs smoothly. Based on the Local Agenda (LA21), the amount is given by the Ministry of Local Government and Housing. We can either obtain the resources or capital from the state depending on the Pahang State Secretary Office or funds from NGO and the community. In order to gather the funding, we go through the Pahang State Secretary Office and from there on, we outline a suitable tourism programme based on their suggestions. But for our involvement, Cameron Highlands District Council will decide whether it is suitable to be implemented depending on current conditions and expected community involvement.

(Respondent 1)

When it comes to tourism programme for community involvement, it is created by the Ministry of Tourism and Culture Malaysia (MOTAC) based on two teams from the Headquarters in Putrajaya and the one in Pahang. But mostly, the tourism programmes for Cameron Highlands are carried out by the Ministry of Tourism and Culture (MOTAC) from the branch here in Pahang itself. The programmes' standard is that it is supported by the Ministry of Local Government and Housing, in terms budget and resources. For instance, we implemented an initiative of upgrading the public toilets here to appeal to the tourists and visitors. The areas affected are Ringlet and Tanah Rata. A budget is given and the upgrading works are carried out. For the community, we also have funds from income tax to maintain and upgrade Ringlet and Tanah Rata.

(Respondent 2)

Component 2: Interview with The Design Professionals

\section{Issues and Impacts of Cameron Highlands Environmental Degradation}

R3 described the issues faced by the local communities in Cameron Highlands revolving around over-development. R5 felt similar due to land-clearing. 
The problems faced by the communities revolve around over-development. Many farms, jungles and hill slopes gave way in the name of development. First, the flash floods caused by soil erosion. For example, continuous heavy rain in October 2013 had caused mud flood in Bertam Valley which took 3 people's life. And then there is water pollution the water quality deterioration of the catchment areas whereby the main rivers and its tributaries caused by serious pollution of organic compounds and siltation. Also, the indigenous people losing their rice bowl from hunting and crops. Deforestation also may cause them to lose the opportunity to earn from eco-tourism activities jungle walk guiding. And then with all of these happening, there is of course climate changes. Prolonged drought also has caused much lower production in agriculture produce. Also, the loss of flora \& fauna where many plants and animals lose their natural habitats.

(Respondent 3)

The slopes in Cameron Highlands are Class 3 and Class $4.80 \%$ of the areas here are categorised as sensitive. During monsoon season during October to March, we face soil erosion. This is also due to the impacts of development and land clearing issues. In the Local Plan, the development areas are being reserved for $8 \%$. We have $3 \%$ out of $8 \%$. There is forest encroachment reported. The climate change is bad. Even at night, the temperature goes down to $26 \%$ and it gets hot and humid at times. The formation of clouds is less and we are exposed to sun. The urban heat generated from Ipoh or Alor Setar rises up to the atmosphere and eventually Cameron Highlands receives more heat. If there are more clouds, it's cooler. Development however is still ongoing due to it being in demand.

(Respondent 5)

\section{Limitations of Tourism Development in Cameron Highlands}

R4 described the limitations in the form of attractions when visiting Cameron Highlands.
When it comes to limitations it includes questions like why tourists want to go to Cameron Highlands? Is it fresh air, food or produce, tea plantations or infrastructure. Or is it the tourism companies and tourist themselves from local and overseas and also is it the space? Is Cameron Highlands able to handle the large 'tourist' crowd?

(Respondent 4)

R5 described the limitations of environmental changes due to agricultural activities.

During the monsoon season in 2014, it was recorded that the rainfall was $1000 \mathrm{~mm}$ equivalent to an annual rainfall. The soil is exposed to high content of water. At Kea Farm, the slope was cut at a very steep manner. This leads to the impacts of soil erosion and landslides. The land clearing for agricultural activities and slope cutting need to be controlled. Near Kuala Terla, there is a gabion wall at 60 feet of height. By law, you are not allowed to exceed 8 feet.

(Respondent 5)

R7 described the limitations of traffic control. While R8 described the climate change

There is no control over traffic. The traffic congestion at Tanah Rata gets worse during holidays and weekends. We had a suggestion of providing shuttle busses with a parking facility in the town. But the local communities were against it. We also proposed cable car, but the local communities were against it also. Due to the reason being nobody would come visit their stores or stalls located at the edges of the roadsides and worried their source of income would decrease.

(Respondent 7)

If temperature increases, crops might not do so well. For instance, tea plantation produce can be an indicator. Is the tea produce getting a smaller output? Past temperature to current temperature plays an important role. Past records of landslides of what is changing in the past 10 to 20 years ago.

(Respondent 8)

R7 described the limitations of traffic control. While R8 described the climate change 
There is no control over traffic. The traffic congestion at Tanah Rata gets worse during holidays and weekends. We had a suggestion of providing shuttle busses with a parking facility in the town. But the local communities were against it. We also proposed cable car, but the local communities were against it also. Due to the reason being nobody would come visit their stores or stalls located at the edges of the roadsides and worried their source of income would decrease.

(Respondent 7)

If temperature increases, crops might not do so well. For instance, tea plantation produce can be an indicator. Is the tea produce getting a smaller output? Past temperature to current temperature plays an important role. Past records of landslides of what is changing in the past 10 to 20 years ago.

(Respondent 8)

\section{Goals of Sustainable Community-based Tourism Programme}

$\mathrm{R} 3$ described the goal is to upraise the socioeconomic status of the community. R5 described the goal is create an awareness for the communities for a clean environment.

It is to bring up the socio-economic status of the community in attraction areas in the highlands especially the indigenous people. Community based programmes in tourism will bridge the gap between the rich and the poor. Homestay concept with local cultural experiences are rarely being offered in other countries. This will give tourists the wide array of experience and options. This provides job opportunities and entrepreneurship to locals. Cottage industry supporting tourism. It helps the young locals to be more productive and reduce crime.

(Respondent 3)

We have campaigns of raising awareness involving communities here with children and implement them in schools. Events such as gotong-royong to create a clean environment for them and tourists.

(Respondent 5)

Component 3: Interview with Community $\underline{\text { Representative /Village Headman }}$
Issues and Impacts of Tourism to the Community

R8 described land clearing to be an impact towards tourism and community.

Cameron Highlands is not a tourism district but an agricultural district. However, Cameron Highlands is also not supposed to be an agricultural district, this is due to the terms and conditions of land clearing for agricultural crops. We have the limit of what is suitable above $1000 \mathrm{~m}$ sea level. Licensing is also an issue being handed out leading to illegal land clearing. We have already called for licensing to be halted back in 2008 for TOL. Most of our communities here depend on agricultural production. The impacts are on them and the people here don't know what the effects are when land clearing happens.

(Respondent 8)

\section{Suitable Tourism Programme with Community Involvement}

$\mathrm{R} 8$ described the replanting of trees programme which was mentioned before by the local authority. He felt that the negative impacts of media exaggerating the environmental issues affected the locals' business here.

We do have campaign raising awareness and educating them the effects of land clearing, programme by Department of Environment (DOE) such as replanting of trees programme. Now, it is being controlled and no open burning. The media also made an impact for the communities here. The number of tourist arrivals decline as issues are being exaggerated in the media. It was during the school holidays where people cancelled bookings and it affected the communities.

(Respondent 8)

Component 4: Interview with The NonGovernmental Organisation (Ngo)

\section{Resources for Suitable Tourism Programme}

R9 described that by giving empowerment to them is important. R10 described that a certain budget shall be provided by the local authority. 
The most important type of resources is empowerment by the community of Orang Asli. This is because they know better of what they need and is best to let them handle it. After all, they have been looking after our forests for years and it is their place of living and issues do not arise because of them. The problem here is, our local communities who are clearing forests as part of our profit. In terms of money, they do need it but very minimal and utilise their surroundings more. Give them power, give empowerment to them that is the best policy.

(Respondent 9).

When they open business to provide tourism services from food and beverage, accommodation and tour packages, but how many are involved as service providers, are they locals? They're outsiders and not the local communities. The local authority need to help by providing a certain budget for the locals to control, manage and maintain the environment or any accommodation they provide for tourists.

(Respondent 10).

\section{Implementation of Community-based Tourism in terms of Social, Economic \& Environmental Aspects}

R9 described that the implementation of tourism programme with community involvement needs to be emphasised more on educational training for the locals.

It is more towards educational programmes involving training. We think that the forest is important and can be part of eco-tourism but we do not have much left. Yes, land is a state matter so it is hard to control. When logging happens, the area becomes hollow and this affects the existing flora and fauna.

(Respondent 9)

R10 described in terms of environmental aspect, forests for keen tourists can be visited but it should be undisturbed.
When you visit the habitats of flora and fauna it should be undisturbed, that is ecological tourism. When you go for that kind of tourism, people want to know about the species. They are keen tourists to know the birds and flowers and they're willing to pay. But not many, 1 or 2 people out of 20 maybe, and if they want to see the community, they want the pristine community.

(Respondent 10)

Opinions of NGO on Tourism Programme or services with Community Involvement in Tanah Rata, Cameron Highlands

R9 described that the agricultural industry offering tourism products should benefit the locals and allow them to have equity benefits.

Even if we implement a programme that includes the Orang Asli community, the community there is actually a minority. The current communities there are locals namely the Chinese and Indians which are farmers and the Malays which are either government servants or village workers. Whenever there is agricultural industry which has existed long time ago, it is not something to diminish. But the agricultural industry offering tourism services or product should also benefit the locals and allow them to have fair benefits. The TOL lands that are being issued without control, we have highlighted this. Slope exceeding 25\% cannot be touched.

(Respondent 9)

R10 described similar traits when it comes to allowing the locals to fairly benefit from the local produce.

When it first started, it was a holiday home or retreat. Tourism has been the main thing. Agriculture is tea plantation and vegetables and legumes are secondary. Nature based tourism is visitation to the allowed nature areas in Cameron Highlands. Sometimes the tour companies do not understand the tourism they offer there. Eco-tourism is to see nature. In Cameron Highlands, it is agritourism for tea, nursery, vegetable plantations and more where it benefits the locals. All these plantations offer tourism or tourism product.

(Respondent 10) 
Technical Challenges of developing a tourism programme with the host community at Tanah Rata, Cameron Highlands

R9 described how land status of TOL lands need to be enforced and its issuance needs to be controlled.

I think technical challenges are more towards the land status such as TOL lands. We do not see any community-based tourism activity here. This is because the communities in Cameron Highlands depend on the cultivation lands. Even if there are challenges, it goes back to the enforcement. For instance, during one of the flash flood cases, there is supposed to be a 10 meters' setback on the left and right side of the river reserve. There should not be any kind of plantations or settlements there, but it has been cultivated. It was supposed to be a river reserve to control the flood, so the technical challenges inclined more towards the enforcement and issuance of TOL lands. Even if there are traveling agencies of tourism companies promoting Cameron Highlands and exposing the highlands and its tourism activities, it has not been successful. This may be due to the developments or how the government or related parties channel their support and help to the locals and communities that will be involved in Cameron Highlands in order to make community-based tourism work.

(Respondent 9)

R10 described the challenges in terms of water and electrical outage due to the number of tourists. It needs to be managed accordingly or have the tourism services organised suitably.

The issue there with tourism is like you have a house and you have guests coming to your house. The community should have control in order to manage these tourists. So how is the community managing them? If the number is double the number of local community, it is not manageable. But how to manage? By controlling the carrying capacity. When tourists come, they are looking for good service. But when it's out of control, hygiene, cleanliness and quality is dropping. Problems like leaking, toilet malfunction and becomes out of their control. Back then there was only 1 road, now they have 3 roads. Back then tourists were not as bad, but now it's very crowded. But budget is also a constraint. The tourists camp illegally and farmers too run illegal farming. It's because too many development and now impacting water catchment leading to mud flood. When double and triple the population, water outage and electrical outage become the issue because it's not enough to sustain. The local tour operators are small because they don't have much budget. The big hotels here are mostly outsiders.

(Respondent 10)

\section{DISCUSSION}

A framework containing the principles in order to manage protected areas such as Cameron Highlands is developed for policymakers and researchers in sustainable tourism or community-based tourism field to enable sustainable practices in tourism development. It is based on the findings from interview sessions and the limits of acceptable change planning framework by Eagles \& McCool (2002).

\section{Principle 1: Objective for Suitable Sustainable Tourism Management}

By setting achievable and progressive objective or objectives as an initiative towards the tourism management of protected forest areas and controlling the number of visitors. Mc Cool (2002) described that objectives are made in order to provide definitive statements towards the management. For instance, management of the highlands' tourism products or highlands' tourism services of an eco-sensitive area. These objectives can either be administrative policy or formal legislative statements (McCool, 2002). However, to produce an objective requires involvement from the government and local stakeholders to unanimously agree in order for the objective or objectives to be developed.

\section{Principle 2: Temporal Tourism Environmental Impacts}

There are a number of temporal impacts coming from visitors or also known as spaces used and occupied by them which are discontinued during their visitation periods. These impacts from the visitors occur offsite and are often less visible from the public however, if it is left unmanaged, it can contribute to long term environmental loss.

Principle 3: Management of Electrical, Sewage, Water \& Waste 
Management issues when there is increase in population or the number of people in Tanah Rata have simple technological solutions such as, electrical and water supply, waste management, parking and sewage (McCool, 2002).

Principle 4: Setting A Limit in Tourism Management

Setting limit policy is viewed as a potential management action to control visitation and puts an emphasis in carrying capacity of the tourists' arrivals (McCool, 2002). This determines the limit of visitations in an ecosensitive area. However, implementing limit policies is a challenging task that includes rationing techniques or allocation deemed to be appropriate for it to be carried out in a certain area.

Based on the Standards of Ecotourism by Weaver \& Lawton (2007), in an eco-sensitive area or any tourism activities related to the natural surroundings and environment, in order to implement sustainability in tourism development, maintenance of carrying capacity needs to be carried out.

Example:

'What the community needs assessment' is carried out by asking the questions as described by Muegge (2016) in effective community decision making where the local community is the host community.

a) What is needed?

The current state of tourism in Tanah Rata, Cameron Highlands remains as a tourist attraction area. However, it does not hold any attributes showing a solid or effective community involvement in tourism or traits of community-based tourism which is needed in an eco-sensitive tourist attraction area.

b) How many have the need?

Resources can be in various forms. For instance, homestay programme or eco-tourism tour guided by the community, the government can consider some of tax exemption on the revenue to encourage tourism. As for community-based tourism operated by indigenous people, government shall provide amenities such as build community halls, upgrade amenities, acquire and maintain some equipment like generator sets in areas with no electricity.

c) Who are they?
The process requires commitments from local authority, Non-Governmental Organisation (NGO), local communities and the local stakeholders.

d) How important is it that this decision/need to be filled?

Empowerment to the community of Orang Asli or locals is important. This is because they know better of what they need and is best to let them handle it.

\section{e) What is already being done?}

The programme that has been implemented is in Taman Sedia Village, Cameron Highlands based on the concept of homestay which is being supported by the Resident Representative Office (ROO) together with the local hosts.

\subsection{Community Involvement in Terms of Sharing of the Tourism Benefits}

Fair-trade schemes of equity in payment are a scheme that favours the local people to benefit off tourism businesses. The scheme is to support the locals involved in agriculture to protect their working and living environment and gain control over their future in tourism businesses. As described by Camp \& Goodman (2005), the issues of fair-trade may seem trivial when compared to other issues faced by the indigenous community such as forced relocation, language barrier, loss of traditional lands and lack of access to health and educational government services. There are financial challenges faced by the indigenous community that they do not have control over.

\subsection{Suitable Tourism Programme for Tanah Rata, Cameron Highlands}

Community Tourism Programme 1: The Homestay concept

This helps to link the cultural heritage and conservation and introduce the sustainable rural living in Cameron Highlands. This can be seen as a tourism product offering tourism services with local hosts. The selected homes are refurbished to an extent where it is at a presentable level for tourists to stay. The families attached to the program shall be trained with sanitation and hygiene knowledge, nutritional meal preparations, waste disposal and handling visitors or guests. By letting the families be the host communities, community tourism will help to empower the families involved economically and exchange cultural values amongst local hosts and tourists. 
Community Tourism Programme 2: Market Access for Emerging Local Tourism Entrepreneurs

Local tour operators providing tourism services run and managed by the local communities can provide market access for emerging local tourism entrepreneurs. They range from tour packages, accommodation and travelling packages. It is best to allow the local communities to provide the travelling and tour package as they possess local culture and a broader knowledge on Cameron Highlands.

Community Tourism Programme 3: The visitors experience

Local festival and events can be held for annual calendar to enhance visitors' experience. Help and support from local stakeholders and local authority to attract more tourists.

\section{CONCLUSION}

Curation of tourism development with community involvement in mind as the market growth to benefit both locals and tourists' travelling experience without deserting the social and environmental aspects is the key concerns in this paper. There were a number of key terms having the same definition or meaning coming from different components when it comes to suitable tourism programme. The key terms that are similar are; local residents invite tourists to discover local habitats or homestay with programmes that provide job opportunities and entrepreneurship to locals, protection of nature and low impact on environment and culture.

Tourism without a doubt appears to be vital in the global economy (Honey \& Gilpin, 2009). Tourism impacts the society, if not for the better. It helps to diversify the sociocultural background and promotes local entrepreneurship. With thorough study, community forums and careful planning, the sustainability of Cameron Highland can be achieved. Through curated tourism programmes, not only will the locals acquire knowledge but will see the potential of local ventures.

\section{REFERENCES}

Ali K., A. T., Sarvenaz H. (2011). The Reciprocal Effects of Architecture and Tourism: The Suitability Approach.

Clarke, K, J. Clark (2000). The Tourism Development Handbook. London, Cassell.

Edwards, L. M. S. a. S. (2007). Tourism,
Indigenous and Local Communities and protected areas in developing Nations. Tourism and protected Areas: benefits Beyond Boundaries. R. B. a. P. F. J. Eagles, CAB International: 71.

Foxlee, J. (2007). Key Principles and Directions for tourism in protected areas: a Review of Existing Charters, Guidelines and Declarations. Tourism and protected Areas: benefits Beyond Boundaries. R. B. a. P. F. J. Eagles, CAB International: 44-70.

George, C. (2000). Environmental Impact Prediction and Evaluation, John Wiley \& Sons, Ltd.

Gourdon, L. C. a. J. (2005). "Is the concept of sustainable tourism sustainable? Developing the Sustainable Tourism Benchmarking Tool." 1-19.

Kasim, A. (2007). "Corporate Environmentalism in the hotel Sector: Evidence of Drivers and barriers in Penang, Malaysia." Journal of Sustainable Tourism 15(6): 680-699.

Mohamed, P. B. (2014). Is Sustainable Tourism and Oxymoron? Earth Matters. Mira. Malaysia.

Sebastian, A. (2015). Making the Case for Sustainable Tourism. Earth Matters. L. C. Lynn. Malaysia.

Sheng-Hshiung T., Y.-C. L., Jo-Hui L. (2005). "Evaluating ecotourism sustainability from the integrated perspective of resource, community and tourism." Tourism Management: 640-653.

Toh P. S., A. H. B. P. B., Justin S., Ramzah D. (2012). "Developing and promoting a highland community livelihood for sustainable tourism: The case of $\mathrm{Kg}$. Bundutuhan, Ranau." Malaysia Journal of Society and Space 8(5): 94-99.

Ostheimer, S. (2013, June 27, 2013). "Cameron Highlands: Malaysia's enduring 'Little England'. Retrieved April 4, 2016, 2016.

Ramli, A. R. (2015). Malaysia wins big at the world travel awards Asia \& Australasia gala ceremony. A. R. Ramli. Malaysia, Tourism Malaysia.

Fleischer, A. \& A. Tchetchik (2005). "Does rural tourism benefit from agriculture?" Tourism management 26(no. 4): 493.

Alexander, J. (2006). Malaysia, Brunei \& Singapore, Cadogan Guides; 1st edition (December 1, 2006).

Atiyah, J. Southeast Asia, Rough Guides; 3rd Edition edition (9 Sept. 2005).

Hall, C. M. (2000). Tourism Planning: Policies, Processes and Relationships. England, Pearson Education Limited.

Colin M. H., S. W. B. (2005). Nature-based Tourism in Peripheral Areas: Development 
Or Disaster?, Channel View Publications, 2005.

"10 Of Malaysia'S Best Eco-Tourism Destinations". Blog.tunehotels.com. N.p., 2016. Retrieved 14 May 2016.

Bhuiyan, Md. A. H., Chamhuri S., \& Shaharuddin M. I. "Tourism Development In Malaysia From The Perspective Of Development Plans". Asian Social Science 9.9 (2013): n. pag. Retrieved 2 May 2016.

Borji, H.S. "Is Malaysia A Developed Country?". investopedia. N.p., 2016. Retrieved 2 May 2016.

The Value Of Activities For Tourism. 1st ed. 2016. Retrieved 4 May 2016.

Wijnen, B. "Cameron Highlands". Malaysiasite.nl. N.p., 2016. Retrieved 4 May 2016.

Easton, S. T. "Is Tourism Just another Commodity? Links between Commodity Trade and Tourism". Journal of Economic Integration 13.3 (1998): 522-543

Hitchner, Sarah L. et al. "Community-Based Transboundary Ecotourism in The Heart Of Borneo: A Case Study Of The Kelabit Highlands Of Malaysia And The Kerayan Highlands Of Indonesia". Journal of Ecotourism 8.2 (2009): 193-213

"Revenue Definition | Investopedia". Investopedia. N.p., 2003

"Wildlife Tourism, Host Communities and Sustainability. Some Thoughts. | Lorton Consulting".

Tourismplanningprofessionals.com. N.p., 2016

"What Factors Affect The Carrying Capacity Of An Environment?". Education.seattlepi.com. N.p., 2016

"Rural-Urban Student and Entrepreneur Exchange | One Montana". Onemontana.org. N.p., 2016

"Learn Online And Feed The Hungry | Freerice.Com". Freerice.com. N.p., 2016

"Number Of Tourist Arrivals To Cameron Highlands On The Decline | Thesundaily". Thesundaily.my. N.p., 2016

Hitchner, Sarah L. et al. "Community-Based Transboundary Ecotourism In The Heart Of Borneo: A Case Study Of The Kelabit Highlands Of Malaysia And The Kerayan Highlands Of Indonesia". Journal of Ecotourism 8.2 (2009): 193-213

Honey, Martha \& Raymond Gilpin. Tourism In The Developing World: Promoting Peace And Reducing Poverty. 1st ed. United States of America: N.p., 2009

Pollock, Anna. "Six Reasons Why Mass Tourism Is Unsustainable". The Guardian.
N.p., 2013

Krause, Linda. "The Economic Impacts of Fair Trade in Tourism". (2012): 4-10

C. GISOLF, Marinus. "Tourists' Roles in A Sustainable Development: Polluters, Mitigators And Believers". Journal of tourism - studies and research in tourism 20 (2015): 8-13

Goodwin, Harold and Rosa S. CommunityBased Tourism: A Success?. 2009. Responsible Tourism.

Sustainable Development: From Brundtland to Rio 2012. New York: N.p., 2010

Kumaran, S and A.N Ainuddin. "Forests, Water and Climate of Cameron Highlands". (2006)

Rancangan Tempatan Daerah Cameron Highlands 2003-2015. Kuala Lumpur: Jabatan Perancangan Bandar dan Desa Semenanjung Malaysia, 2000. Print.

Cameron Highlands Info (2009-2013). History of Cameron Highlands. Retrieved 27 October $2016 \quad$ from www.cameronhighlandsinfo.com

Fairtrade Foundation (2016). What Fairtrade Does? Retrieved 28 October 2016 from www.fairtrade.org.uk

Holden, Andrew and David A Fennell. The Routledge Handbook of Tourism and The Environment. New York: Routledge, 2013. Print.

Weaver, David B. Sustainable Tourism. Amsterdam: Elsevier ButterworthHeinemann, 2006. Print.

"What Fairtrade Does | Fairtrade Foundation". Fairtrade.org.uk. N.p., 2016. Web. 27 Oct. 2016.

"Content Curation Is the Future - Digital Tourism Think Tank | Digital Tourism Think Tank". Digital Tourism Think Tank. N.p., 2016. Web. 4 Nov. 2016.

Matarrita-Cascante, David and A. E Luloff. Consequences of Tourism-Based Growth on Rural Communities' Quality Of Life. 2008. Print.

Dikko, M. (2016). Establishing Construct Validity and Reliability: Pilot Testing of a Qualitative Interview for Research in Takaful (Islamic Insurance). The Qualitative Report, 21(3), 521-528. Retrieved from http://nsuworks.nova.edu/tqr/vol21/iss3/6

Miralbell, Oriol, Aurkene Alzua-Sorzabal, and Jon Kepa Gerrikagoitia. "Content Curation And Narrative Tourism Marketing". (2016): n. pag. Print.

"The Role Of The Community Representative". (2014): n. pag. Print.

"Non-Governmental Organizations ". Gdrc.org. 